\title{
Anti-HER2 Monoclonal Antibody CT-P6
}

National Cancer Institute

\section{Source}

National Cancer Institute. Anti-HER2 Monoclonal Antibody CT-P6. NCI Thesaurus. Code C90579.

A monoclonal antibody directed ag ainst the human epidermal growth factor receptor 2 (HER2) with potential immunomodulating and antineoplastic activity. After binding to HER2 on the tumor cell surface, anti-HER2 monoclonal antibody CT-P6 may induce a cytotoxic T-lymphocyte (CTL) as well as an antibody-dependent cell-mediated cytotoxicity (ADCC) against tumor cells that overexpress HER2. HER2, a tyrosine kinase receptor, is overexpressed by many cancer cell types. 